\title{
Trichomes and hydrocarbons associated with the tomato plant antixenosis to the leafminer
}

\author{
MARIA ELISA S. FERNANDES ${ }^{1}$, FLÁVIO L. FERNANDES ${ }^{2}$, DERLY J.H. SILVA ${ }^{3}$, \\ MARCELO C. PICANÇO ${ }^{4}$, GULAB N. JHAMC ${ }^{5}$, PEDRO C. CARNEIRO ${ }^{6}$ and RENAN B. QUEIROZ ${ }^{4}$ \\ ${ }^{1}$ Universidade Federal Rural da Amazônia, Campus de Capitão Poço, \\ Rodovia PA 124, Km 0, Bairro Vila Nova, 68650-000 Capitão Poço, PA, Brasil \\ ${ }^{2}$ Universidade Federal de Viçosa, Campus de Rio Paranaíba, Instituto de Ciências Agrárias, \\ Rodovia BR 354, Km 310, 38810-000 Rio Paranaíba, MG, Brasil \\ ${ }^{3}$ Universidade Federal de Viçosa, Departamento de Fitotecnia, Avenida Peter Henry Rolfs, s/n, 36570-000 Viçosa, MG, Brasil \\ ${ }^{4}$ Universidade Federal de Viçosa, Departamento de Entomologia, Avenida Peter Henry Rolfs, s/n, 36570-000 Viçosa, MG, Brasil \\ ${ }^{5}$ Universidade Federal de Viçosa, Departamento de Química,Avenida Peter Henry Rolfs, s/n, 36570-000 Viçosa, MG, Brasil \\ ${ }^{6}$ Universidade Federal de Viçosa, Departamento de Biologia Geral, Avenida Peter Henry Rolfs, s/n, 36570-000 Viçosa, MG, Brasil
}

Manuscript received on November 3, 2010; accepted for publication on April 4, 2011

\begin{abstract}
The objective of this work was to study the density of trichomes and hydrocarbons associated with the resistance by antixenosis of 42 subsamples of tomato plants from the Horticultural Germplasm Bank of the Universidade Federal de Viçosa (HGB-UFV) to Liriomyza trifolii. These subsamples were studied in addition to 'Santa Clara' cultivar, which was used as a standard of susceptibility to leafminers. The evaluated characteristics were the number of mined leaflets per plant, mines per plant, trichome density and chemical compounds in the leaves. Differences were detected among the subsamples in the variables studied. We identified 20 peaks in the chromatograms of leaf hexane extract the subsamples tested. The subsamples HGBs - 216, 813, 985, 987, 991, 992, 993, 1532, 1989, 1991, 2048, 2055, 2064 , 2068, 2073, 2075, 2089, 2096 and 2097 were selected as sources of resistance to L. trifolii. The resistance mechanism associated to these subsamples was antixenosis. In addition, the low density of trichomes and the chemical compounds in the subsamples can be possible causes of pest resistance.
\end{abstract}

Key words: Liriomyza trifolii, Solanum lycopersicum, germplasm, pest resistance.

\section{INTRODUCTION}

The tomato plant (Solanum lycopersicum Mill.) (Spooner et al. 1993, Peralta et al. 2005) is one of the most important vegetables grown in the world that has serious diseases and pests problems (Suinaga et al. 2003). Among pests, the leafminer Liriomyza

Correspondence to: Maria Elisa de Sena Fernandes

E-mail:mariaelisasena@yahoo.com.br trifolii (Burgess) (Diptera: Agromyzidae) is an important pest of this crop (Parrella et al. 1981).

Damages caused by larvae consist in opening sinuous galleries between the upper and lower epidermis of leaves that form whitish lesions, which may penetrate the veins. When this population of pes larvae is high, there is a significant photosynthetic area reduction, causing wilting and premature leaf 
fall. The adults feed on the leaf exudation through the puncture made by females with ovipositor (Parrella 1987, Parrella et al. 1981).

The main method of crop management to control this pest insect is chemicals. The use of insecticides as the only or main form of management may cause damage to the environment, harm to the health of rural workers and consumers, and increased spraying costs (Souza and Reis 1999). The use of tomato cultivars resistant to the leafminer can be a viable alternative due to the high cost of spraying and the problems cited.

One of the difficulties in obtaining a resistant variety is the low genetic variability that often prevents a breeding program. The genetic variability can be obtained by sources of resistance that are present mainly in germplasm banks. Tomato plant subsamples of the horticultural germplasm bank of the Universidade Federal de Viçosa have been tested for the tomato leafminer Tuta absoluta (Lepidoptera: Gelechiidae) (Oliveira et al. 2009) and whitefly Bemisia tabaci biotype B (Hemiptera: Aleyrodidae) (Fernandes et al. 2009). Although there are studies about pests on tomato plants, there are no studies that identify subsamples of the germplasm bank that are is resistant to L. trifolii.

In the process of obtaining cultivars resistant to pests it is also important to study the mechanisms and causes of resistance. There are three mechanisms that may be involved in the resistance of Solanum spp. to arthropod pests: antixenosis, antibiosis and tolerance. The causes may be trichomes, chemical compounds and/or physical morphology, which may be associated with resistance (Panda and Krush 1995).

Given the need to search for sources of genetic variability, the lack of studies about new subsamples from the horticultural germplasm bank and the scarcity of studies assessing the resistance mechanisms and causes, the aim of this work was to study the density of trichomes and hydrocarbons associated with resistance by antixenosis of 42 subsamples of tomato plants from the Horticultural
Germplasm Bank of the Federal University of Viçosa (HGB-UFV) to Liriomyza trifolii.

\section{MATERIALS AND METHODS}

REARING OF L. trifolii

To initiate the rearing, adults leafminers were collected in commercial tomato crops in Viçosa-MG. The rearing was held in $50 \times 50 \times 50 \mathrm{~cm}$ wooden cages covered with organza at the Integrated Pest Management Laboratory at the Universidade Federal de Viçosa (UFV) in kale plants (Brassica oleracea var. acephala) to avoid pre-imaginal conditioning (Panda and Krush 1995). Weekly, kale plants without the infestation of leafminers and other insects were added.

EVALUATION OF THE Resistance of TOMATO PLANT SUBSAMPLES TO $L$. trifolii

The evaluation of the resistance of tomato subsamples to L. trifolii was conducted in a greenhouse at the UFV from August to December in 2008. We studied 42 subsamples of tomato plants from the HGB-UFV, in addition to 'Santa Clara' cultivar that was used as a standard of susceptibility to leafminers (Fancelli et al. 2003).

The tomato plant seedlings were transplanted to 500 milliliter plastic pots containing dirt + tanned cow manure $(2: 1)$, and the practices were performed according to Silva et al. (2008). The experimental design was completely randomized with three replications. Each experimental plot consisted of a plastic pot containing one tomato plant with six totally expanded leaves. The treatments were the 42 subsamples and 'Santa Clara'. For the experiment, 300 adult leafminers were released in the central part of the greenhouse.

The evaluated characteristics were the number of mined leaflets per plant and mines per plant. The number of mined leaves and mines was evaluated by performing a direct counting of these features throughout the plant five days after infestation. 
Evaluation OF the Causes of Resistant of Tomato PLANT SUBSAMPLES TO L. trifolii

\section{Trichomes}

The first fully expanded leaf was collected from the apex of each subsample. The first leaflet located toward the apex of the leaf base of this leaf in an area of $0.04 \mathrm{~cm}^{2}$ on the left side without overlaping the region of leaf veins was evaluated. The number counting of trichomes was performed using a stereomicroscope (SMZ-140 Series: Motic) with 40× magnification (Fernandes et al. 2009).

\section{Chemical compounds}

In each tomato subsample, $10 \mathrm{~g}$ of leaves were collected randomly. This sample was immersed for 24 hours in $100 \mathrm{~mL}$ of bidistilled hexane PA $\left(\mathrm{CRQr}^{\circledR}\right)$ in $250 \mathrm{~mL}$ Erlenmeyer flasks sealed with aluminum foil and parafilm for the extraction of compounds. The hexane solution was concentrated in a rotary evaporator (Marconi MA-120V) at $45^{\circ}$ and kept a pressure of $530 \mathrm{~mm} \mathrm{Hg}$. The extracts were stored in glass vials $(8 \mathrm{~mL})$ and kept under in a freezer (Eloplus, Bosch) at $-18^{\circ} \mathrm{C}$ until the completion of the chromatographic analysis.

Chemical analyses were performed on a gas chromatograph coupled to the mass spectrometry (GC/MS) (Shimadzu, model CGMS/QP 5000). This GC/MS was coupled to a microcomputer with the program GC Solution for the recording and analysis of chromatograms. The compounds were separated and identified in a DB-5 capillary column $(30 \mathrm{~m} \times$ $0.25 \mathrm{~mm}$ ). For the chromatographic separation, a $1 \mu \mathrm{L}$ sample was injected using L syringe (Hamilton ${ }^{\circledR}$ ) in the Split system $=5$. Helium was used as a carrier with a scheduled linear velocity at $39.5 \mathrm{~cm} / \mathrm{s}$.

The injector temperatures and detector were $220^{\circ} \mathrm{C}$ and $240^{\circ}$, respectively. The column temperature was maintained for 10 minutes at $40^{\circ} \mathrm{C}$, and this was increased at $10^{\circ}$ per minute until reaching $280^{\circ}$, remaining at this temperature for 26 more minutes, which totals 60 minutes of analysis. The carrier gas flow in the column was $1.2 \mathrm{~mL} / \mathrm{min}$. The mass was scanned from 40 to $400 \mathrm{~m} / \mathrm{z}$. The identification of compounds was accomplished using the retention time of standards contained in the library (Library Editor) "John Wiley" 7 with 220,000 compounds.

\section{STATISTICAL ANALYSIS}

Data about the number of mined leaflets, number of mines per plant and trichome density per $0.04 \mathrm{~cm}^{2}$ were submitted to the Lilliefors and Cochran tests in order to check whether they conformed to assumptions of homogeneity of variance and normality of errors, respectively (Cochran 1947). Subsequently, they were submitted to the analysis of variance and their means were compared by the Scott-Knott test at $\mathrm{p}<0.05$ (Scott and Knott 1974). Pearson's correlation analysis was performed between the L. trifolii density and the hydrocarbon concentrations obtained from the leaf extracts of the tomato plant subsamples of the HGB-UFV.

\section{RESULTS AND DISCUSSION}

Significant differences in the number of mined leaflets by L. trifolii $\left(\mathrm{F}_{(42,86)}=2.27, \mathrm{p}<0.001\right)$ were detected in the subsamples from the UFV. Seventyseven percent of the subsamples had low densities of mined leaflets per subsample. Among these subsamples there are HGBs-2055, 2057 and 2127. The subsamples with the highest number of mined leaflets were HGBs-988, 989, 1490, 1497, 2060, 2065, 2088, 2095, 2100 and 2112 (Table I).

There are significant differences in the number of mines of L. trifolii $\left(\mathrm{F}_{(42,86)}=2.02, \mathrm{p}<0.001\right)$ among the HGB-UFV subsamples. Thirty-five percent of the subsamples showed a lower number of mines. Among these subsamples, the HGB-2057 showed lower infestation, while the HGB-2127 did not show mines. The subsample with the largest number of mines per plant was HGB-2065 (Table I). 
Differences in densities of subsamples of $L$. trifolii from the UFV may have occurred because of genetic variability among different subsamples. This is because the 42 evaluated subsamples are from different regions of Brazil and the world (Table II). According to Panda and Khush (1995) one of the ways to get genetic variability is to get plants from different regions. Marim et al. (2009) found high variability among 70 tomato plant subsamples of the the for morphological and agronomic characteristics that vary according to the location of collection.

Genetic variability is one of the characteristics of the germplasm bank subsamples that gives higher or lower susceptibility to pest insects.

Among these characteristics there is food quality, which consists of compounds that stimulate or inhibit the feeding of pest insects, such as lignin and morphological structures to protect the eggs, trichomes and chemical compounds such as volatile compounds (terpenes) and others (Carr and Eubanks 2002, Blossey and Hunt-Joshi 2003, Dudareva and Qualley 2008).

Thus, the low insect density to the characteristics of number of mined leaflets and mines per leaf of HGBs-216, 813, 985, 987, 991, 992, 1532, 1985, 1989, 1991, 2004, 2008, 2009, 2017, 2048, 2055, 2057, 2064, 2068, 2073, 2075, 2083, 2089, 2096, 2097, 2098, 2116, 2122 and 2127 coming from 42 subsamples may be associated with the antixenosis mechanism. Also known as nonpreference, insects show less preference for oviposition, food or shelter due to chemical, morphological and/or physical stimuli provided by plants, which are governed by genetic factors that cause different responses in insects (Painter 1951, Panda and Krush 1995).

The resistance of tomato plants of S. lycopersicum has been studied to identify mechanisms that confer resistance to arthropod pests (Kennedy 2002). Oliveira et al. (2009) observed that the HGB 1497 subsample of $S$. lycopersicum presented resistance by antixenosis to the tomato plant miner T. absoluta.
In addition to detecting the type of resistance mechanism of the subsamples from the UFV, the morphological and chemical characteristics that would be possible causes of this resistance were identified.

Significant differences were observed in the number of trichomes per $0.04 \mathrm{~cm}^{2}$ of leaf $\left(\mathrm{F}_{(42.86)}=\right.$ $4.57, \mathrm{p}<0.001)$ among the subsamples. Twenty nine samples out of the 43 showed lower density. The subsample with lower and higher trichome densities were HGB-2060 and HGB-1490, respectively (Table I). Goffreda et al. (1990) and Gonçalves et al. (2006) found that trichome density is directly related to pest resistance in the tomato plant. The highest densities are associated with the largest number of leaflets and mines per plant, which may be due to the fact that these subsamples of the tomato plant provide a favorable microclimate to the larvae development (Butter and Vir 1989). As we know that the offspring performance is determined by the choice of adult insects for oviposition (Thompson 1988, Mayhew1997, 2001), the lowdensity of trichomes on tomato leaves can be extremely important for a subsample to avoid the presence of L. trifolli. Thus it can be used in improvement programs with selections toward genes that express a lower number of trichomes.

Besides the morphological cause, the chemical cause was found. Twenty peaks were identified in the chromatograms of leaf hexane extracts of 42 of tomato plants from the UFV subsamples that were evaluated. These peaks corresponded to hydrocarbons of $9,10,11,12,13,14,15,16,17,18,19,20,21,22$, $24,25,26,28,29$ and 30 carbons, which are called nonane, decane, undecane, dodecane, tridecane, tetradecane, pentadecane, hexadecane, heptadecane, octadecane nonadecane, eicosane, herreicosane, docosane, tetracosane, pentacosane, hexacosane, octacosane, nonacosane and triacontane, respectively.

Of the twenty identified hydrocarbons, only nonane (C9), decane (C10) and nonacosane (C29) were significantly correlated $(\mathrm{p}<0.05)$ to the number of mined leaflets after infestation, meanwhile the 
TABLE I

Number (mean \pm standard error) of mined leaflets, number of mines of Liriomyza trifolii (Diptera: Agromyzidae) per plant and trichomes per $0.04 \mathrm{~cm}^{2}$ of leaf in subsamples of tomato plants from of the Federal University of Viçosa.

\begin{tabular}{|c|c|c|c|c|c|}
\hline Subsample & Mined leaves* & HGB & Number of mines* & HGB & Trichomes $/ 0.04 \mathrm{~cm}^{2 *}$ \\
\hline HGB-497 & $8.33 \pm 0.33 \mathrm{a}$ & 2065 & $10.33 \pm 3.28 \mathrm{a}$ & 1490 & $364.00 \pm 98.73 \mathrm{a}$ \\
\hline HGB-2060 & $7.33 \pm 3.53 \mathrm{a}$ & 1497 & $9.33 \pm 0.67 \mathrm{a}$ & 2098 & $320.00 \pm 11.02 \mathrm{a}$ \\
\hline HGB-2112 & $7.00 \pm 1.53 \mathrm{a}$ & 2100 & $9.33 \pm 3.84 \mathrm{a}$ & 2009 & $316.67 \pm 21.07 \mathrm{a}$ \\
\hline HGB-2065 & $6.67 \pm 1.45 \mathrm{a}$ & 988 & $8.33 \pm 0.33 \mathrm{a}$ & 2004 & $303.00 \pm 59.47 \mathrm{a}$ \\
\hline HGB-988 & $6.33 \pm 0.33 a$ & 2112 & $8.33 \pm 1.45 \mathrm{a}$ & 2122 & $296.33 \pm 62.96 \mathrm{a}$ \\
\hline HGB-2100 & $5.33 \pm 0.88 \mathrm{a}$ & 1490 & $7.00 \pm 3.61 \mathrm{a}$ & 2100 & $288.33 \pm 10.93 \mathrm{a}$ \\
\hline HGB-989 & $4.67 \pm 1.20 \mathrm{a}$ & 2060 & $6.67 \pm 3.28 \mathrm{a}$ & 2017 & $275.67 \pm 53.98 \mathrm{a}$ \\
\hline HGB-1490 & $4.67 \pm 2.33 \mathrm{a}$ & 2113 & $6.00 \pm 3.21 \mathrm{a}$ & 1497 & $264.67 \pm 1.20 \mathrm{a}$ \\
\hline HGB-2088 & $4.33 \pm 1.20 \mathrm{a}$ & 2095 & $5.67 \pm 1.76 b$ & 2127 & $255.00 \pm 33.49 \mathrm{a}$ \\
\hline HGB-2095 & $4.33 \pm 2.03 \mathrm{a}$ & 989 & $5.00 \pm 1.15 \mathrm{~b}$ & 1985 & $250.67 \pm 35.51 \mathrm{a}$ \\
\hline HGB-1532 & $3.67 \pm 0.67 b$ & 216 & $4.67 \pm 2.40 \mathrm{~b}$ & 2008 & $249.67 \pm 25.69 \mathrm{a}$ \\
\hline HGB-2075 & $3.67 \pm 0.88 b$ & 2064 & $4.67 \pm 1.76 \mathrm{~b}$ & 978 & $226.67 \pm 8.82 \mathrm{a}$ \\
\hline HGB-2113 & $3.67 \pm 1.86 b$ & 2075 & $4.67 \pm 1.76 b$ & 2116 & $224.50 \pm 21.98 \mathrm{a}$ \\
\hline HGB-216 & $3.33 \pm 1.76 b$ & 2088 & $4.33 \pm 1.20 \mathrm{~b}$ & 2083 & $217.67 \pm 36.66 \mathrm{a}$ \\
\hline HGB-987 & $3.33 \pm 0.88 b$ & 985 & $4.00 \pm 1.73 \mathrm{~b}$ & 2057 & $196.67 \pm 38.27 b$ \\
\hline HGB-1991 & $3.33 \pm 0.88 b$ & 987 & $4.00 \pm 1.15 \mathrm{~b}$ & 992 & $187.00 \pm 1.53 \mathrm{~b}$ \\
\hline HGB-2048 & $3.33 \pm 1.86 b$ & 2122 & $4.00 \pm 1.00 \mathrm{~b}$ & 993 & $176.33 \pm 16.22 b$ \\
\hline HGB-2116 & $3.33 \pm 0.33 b$ & 1532 & $3.67 \pm 0.67 \mathrm{~b}$ & $1 * *$ & $168.67 \pm 30.85 b$ \\
\hline HGB-2122 & $3.33 \pm 0.88 b$ & 1991 & $3.67 \pm 1.20 \mathrm{~b}$ & 989 & $160.67 \pm 47.05 b$ \\
\hline HGB-978 & $3.00 \pm 2.08 \mathrm{~b}$ & 2004 & $3.67 \pm 1.67 \mathrm{~b}$ & 2068 & $157.67 \pm 36.38 b$ \\
\hline HGB-2008 & $3.00 \pm 2.08 b$ & 2048 & $3.67 \pm 2.19 \mathrm{~b}$ & 2089 & $145.33 \pm 2.91 \mathrm{~b}$ \\
\hline HGB-2064 & $3.00 \pm 0.58 b$ & 2089 & $3.67 \pm 2.67 \mathrm{~b}$ & 2096 & $144.00 \pm 0.58 \mathrm{~b}$ \\
\hline HGB-985 & $2.67 \pm 0.88 b$ & 2116 & $3.67 \pm 0.88 b$ & 2073 & $138.67 \pm 0.88 b$ \\
\hline HGB-2004 & $2.67 \pm 0.67 b$ & 813 & $3.33 \pm 0.33 b$ & 1532 & $137.67 \pm 40.19 b$ \\
\hline HGB-2083 & $2.33 \pm 0.88 b$ & 978 & $3.33 \pm 2.40 \mathrm{~b}$ & 2097 & $137.00 \pm 0.58 b$ \\
\hline HGB-2089 & $2.33 \pm 1.33 b$ & 2008 & $3.33 \pm 2.40 \mathrm{~b}$ & 2112 & $134.00 \pm 40.45 b$ \\
\hline HGB-2097 & $2.33 \pm 1.20 \mathrm{~b}$ & 2009 & $3.00 \pm 2.08 b$ & 1989 & $133.67 \pm 40.70 b$ \\
\hline HGB-813 & $2.00 \pm 0.58 b$ & 2083 & $3.00 \pm 1.53 \mathrm{~b}$ & 1991 & $133.00 \pm 40.82 b$ \\
\hline HGB-2098 & $2.00 \pm 1.53 \mathrm{~b}$ & 2098 & $2.33 \pm 1.86 b$ & 2088 & $133.00 \pm 40.82 b$ \\
\hline HGB-2009 & $1.67 \pm 0.88 b$ & 992 & $2.00 \pm 1.00 \mathrm{~b}$ & 2065 & $131.33 \pm 23.17 b$ \\
\hline HGB-2017 & $1.67 \pm 0.33 \mathrm{~b}$ & 1985 & $2.00 \pm 1.00 \mathrm{~b}$ & 216 & $124.00 \pm 13.00 \mathrm{~b}$ \\
\hline HGB-2068 & $1.67 \pm 0.33 b$ & 2073 & $2.00 \pm 1.00 \mathrm{~b}$ & 813 & $120.00 \pm 25.12 b$ \\
\hline HGB-991 & $1.33 \pm 0.33 b$ & 2017 & $1.67 \pm 0.33 b$ & 985 & $119.33 \pm 8.57 \mathrm{~b}$ \\
\hline HGB-992 & $1.33 \pm 0.67 b$ & 2068 & $1.67 \pm 0.33 b$ & 2048 & $115.00 \pm 0.58 b$ \\
\hline HGB-993 & $1.33 \pm 0.33 b$ & 2096 & $1.67 \pm 1.20 \mathrm{~b}$ & 2113 & $109.00 \pm 0.58 \mathrm{~b}$ \\
\hline HGB-1985 & $1.33 \pm 0.33 b$ & 2097 & $1.67 \pm 0.88 b$ & 991 & $105.67 \pm 0.67 b$ \\
\hline HGB-2073 & $1.33 \pm 0.67 \mathrm{~b}$ & 991 & $1.33 \pm 0.33 b$ & 987 & $103.67 \pm 11.57 \mathrm{~b}$ \\
\hline HGB-2096 & $1.33 \pm 0.88 b$ & 993 & $1.33 \pm 0.33 b$ & 2064 & $101.33 \pm 3.28 b$ \\
\hline $1 * *$ & $1.00 \pm 1.00 \mathrm{~b}$ & 1989 & $1.33 \pm 1.33 \mathrm{~b}$ & 2055 & $96.33 \pm 5.93 b$ \\
\hline HGB-1989 & $1.00 \pm 1.00 \mathrm{~b}$ & $1^{* *}$ & $1.00 \pm 1.00 \mathrm{~b}$ & 2075 & $94.00 \pm 0.58 b$ \\
\hline HGB-2055 & $0.67 \pm 0.33 b$ & 2055 & $1.00 \pm 0.58 \mathrm{~b}$ & 2095 & $87.00 \pm 0.58 \mathrm{~b}$ \\
\hline HGB-2057 & $0.33 \pm 0.33 b$ & 2057 & $0.33 \pm 0.33 b$ & 988 & $86.00 \pm 3.06 b$ \\
\hline HGB-2127 & $0.00 \pm 0.00 \mathrm{~b}$ & 2127 & $0.00 \pm 0.00 \mathrm{~b}$ & 2060 & $74.00 \pm 6.66 \mathrm{~b}$ \\
\hline
\end{tabular}

*Means followed by the same letter in the column belong to the same group by Scott-Knott test at $\mathrm{p}<0.05$; $1 * *$ 'Santa Clara'. 
TABLE II

Origin and year of harvest of the tomato plant subsamples from the Horticultural Germplasm Bank of the Federal University of Viçosa (HGB-UFV).

\begin{tabular}{|c|c|c|}
\hline Subsample & Origin & Year of harvest \\
\hline HGB-216 & Vitória do Santo Antão, PE & 1966 \\
\hline HGB-813 & Cuiabá, MT & 1967 \\
\hline HGB-978 & Campinas, São Paulo & 1966 \\
\hline HGB-985 & Campinas, São Paulo & 1966 \\
\hline HGB-987 & Campinas, São Paulo & 1966 \\
\hline HGB-988 & Campinas, São Paulo & 1966 \\
\hline HGB-989 & Campinas, São Paulo & 1966 \\
\hline HGB-991 & Campinas, São Paulo & 1966 \\
\hline HGB-992 & Campinas, São Paulo & 1966 \\
\hline HGB-993 & Campinas, São Paulo & 1966 \\
\hline HGB-1490 & São Paulo, São Paulo & 1967 \\
\hline HGB-1497 & São Paulo, São Paulo & 1967 \\
\hline HGB-1532 & Belo Horizonte, MG & 1967 \\
\hline HGB-1985 & West Lafayete, USA & 1966 \\
\hline HGB-1989 & West Lafayete, USA & 1966 \\
\hline HGB-1991 & West Lafayete, USA & 1966 \\
\hline HGB-2004 & Purdue University, USA & 1966 \\
\hline HGB-2008 & Purdue University, USA & 1966 \\
\hline HGB-2009 & Purdue University, USA & 1966 \\
\hline HGB-2017 & Purdue University, USA & 1966 \\
\hline HGB-2048 & Purdue University, USA & 1966 \\
\hline HGB-2055 & Purdue University, USA & 1966 \\
\hline HGB-2057 & Purdue University, USA & 1966 \\
\hline HGB-2060 & Purdue University, USA & 1966 \\
\hline HGB-2064 & Purdue University, USA & 1966 \\
\hline HGB-2065 & Purdue University, USA & 1966 \\
\hline HGB-2068 & Purdue University, USA & 1966 \\
\hline HGB-2073 & Purdue University, USA & 1966 \\
\hline HGB-2075 & Purdue University, USA & 1966 \\
\hline HGB-2083 & Purdue University, USA & 1966 \\
\hline HGB-2088 & Purdue University, USA & 1966 \\
\hline HGB-2089 & Purdue University, USA & 1966 \\
\hline HGB-2095 & Purdue University, USA & 1966 \\
\hline HGB-2096 & Purdue University, USA & 1966 \\
\hline HGB-2097 & Purdue University, USA & 1966 \\
\hline HGB-2098 & Purdue University, USA & 1966 \\
\hline HGB-2100 & Purdue University, USA & 1966 \\
\hline HGB-2112 & Purdue University, USA & 1966 \\
\hline HGB-2113 & Purdue University, USA & 1966 \\
\hline HGB-2116 & Purdue University, USA & 1966 \\
\hline HGB-2122 & Purdue University, USA & 1966 \\
\hline HGB-2127 & Purdue University, USA & 1966 \\
\hline
\end{tabular}

Source: http://www.ufv.br/bgh/files/pag/tomate.htm. 
TABLE III

Pearson correlations among the evaluated characteristics of Liriomyza trifolii (Diptera: Agromyzidae) in tomato plant subsamples from the Horticultural Germplasm Bank of the UFV and hydrocarbon concentrations obtained from leaf hexane extracts.

\begin{tabular}{c|l|l|l|c}
\hline Peak & \multicolumn{1}{|c|}{ Hydrocarbons } & Response & Evaluated characteristics & Correlations \\
\hline 1 & C9 (nonane) & Susceptibility & Number of mined leaflets after infestation & $0.32^{*}$ \\
2 & C10 (decane) & Susceptibility & Number of mined leaflets after infestation & $0.32 *$ \\
19 & C29 (nonacosane) & Susceptibility & Number of mined leaflets after infestation & $0.31^{*}$ \\
1 & C9 (nonane) & Susceptibility & Number of mines after infestation & $0.31^{*}$ \\
14 & C22 (docosane) & Susceptibility & Number of mines after infestation & $0.40^{*}$ \\
19 & C29 (nonacacosane) & Susceptibility & Number of mines after infestation & $0.37^{*}$ \\
\hline
\end{tabular}

*Significant correlation at $\mathrm{p}<0.05$ by $\mathrm{t}$ test.

nonane (C9), docosane (C22) and nonacosane (C29) showed significant positive correlations $(\mathrm{p}<0.05)$ to the number of mines after infestation by L. trifolii per plant (Table III).

Thus, the compounds identified in the subsamples are hydrocarbons, and they are associated with greater a susceptibility. There are no studies about tomato plants that associate the concentration of these compounds with the attack by L. trifolli. However, Oliveira et al. (2009) observed positive and significant correlations of hydrocarbons with the attack by $T$. absoluta in the HGB-UFV subsamples. Oliveira et al. (2009) observed in some subsamples a positive and significant correlation between tetracosane and hexacosane concentrations and the susceptibility to attack by $T$. absoluta. The subsamples HGB-7236 and 243 with a higher percentage of mined leaves had higher tetracosane concentrations, suggesting their susceptibility to $T$. absoluta (Oliveira et al. 2009). Suinaga et al. (1999) also attributed the $S$. lycopersicum susceptibility to T. absoluta because of the presence of tetracosane. In addition, Suinaga et al. (1999) demonstrated that heptadecane was the main compound associated with the reduction of the number and viability of leafminer eggs of tomato plant in L. peruvianum. According to Yang et al. (1993), the effect of each compound may influence the presence of other compounds.

All compounds identified in this work are hydrocarbons. These compounds have low molecular weight and are components of the lipid layer of the plant cuticle surface they can also be a chemical barrier to insect attack (Schoonhoven et al. 2005). According to Eigenbrode and Espelie (1995), differences in the lipid layer composition can explain the variation in the level of resistance to herbivore insects. This variation can exist among species, in subsamples within species and among different plant structures in the same plant. However, there are no studies that examine the relationships of these compounds to L. trifolii in tomato plants.

From this work it was observed that some compounds explain the susceptibility in some samples, which can be of great importance in breeding pro grams, since these compounds can be used as chemical markers in the study of tomato plant resistance to L. trifolli. Furthermore, it was observed that there is a genetic variability among the studied subsamples and different levels of resistance to L. trifolii. The results are still preliminary, but there is potential for further studies to be conducted, since studies of resistance of cultivated species to pests are still incipient.

\section{CONCLUSIONS}

The subsamples HGBs-216, 813, 985, 987, 991, 992, 993, 1532, 1989, 1991, 2048, 2055, 2064, 2068, 2073, 2075, 2089, 2096, 2097 and 2127 are sources of resistance to $L$. trifolii. The mechanism 
of resistance associated with these subsamples is antixenosis. Furthermore, the low density of trichomes and chemical compounds present in the evaluated subsamples can be one of the possible causes of resistance to pests, which can be of great importance in breeding programs since these characteristics can be used as markers to study tomato plant resistance to $L$. trifolii.

\section{ACKNOWLEDGMENTS}

Financial support from the Brazilian governamental agencies Conselho Nacional de Desenvolvimento Científico e Tecnológico (CNPq) and Fundação de Amparo à Pesquisa do Estado de Minas Gerais (FAPEMIG) is acknowledged.

\section{RESUMO}

O objetivo desse trabalho foi estudar a densidade de tricomas e os hidrocarbonetos associados à resistência por antixenose de 42 subamostras de tomateiro do Banco de Germoplasma de Hortaliças da Universidade Federal de Viçosa (BGH-UFV) a Liriomyza trifolii. Essas subamostras foram estudadas e a cultivar 'Santa Clara' que foi utilizada como padrão de suscetibilidade a insetos minadores. As características avaliadas foram os números de folíolos minados/planta, minas/ planta, densidade de tricomas e compostos químicos presentes nas folhas. Detectaram-se diferenças entre as subamostras nas variáveis avaliadas. Foram identificados 20 picos nos cromatogramas dos extratos hexânicos das folhas das subamostras testadas. As subamostras HGBs - 216, 813, 985, 987, 991, 992, 993, 1532, 1989, 1991, 2048, 2055, 2064, 2068, 2073, 2075, 2089, 2096 e 2097 foram selecionadas como fontes de resistência a L. trifolii. O mecanismo de resistência associado dessas subamostras foi a antixenose. Além disso, a baixa densidade de tricomas e compostos químicos presentes nas subamostras avaliadas podem ser as possíveis causas da resistência à praga.

Palavras-chave: Liriomyza trifolii, Solanum lycopersicum, germoplasma, resistência a pragas.

\section{REFERENCES}

Blossey B And Hunt-Joshi TR. 2003. Belowground herbivory by insects: Influence on plants and aboveground herbivores. Annu Rev Entomol 48: 521-547.

BUTTER NS AND VIR BK. 1989. Morphological basis of resistance in cotton to the whitefly Bemisia tabaci. Phytoparasitica 17: 251-261.

CARR DE AND EUBANKS MD. 2002. Inbreeding alters resistance to insect herbivory and host plant quality in Mimulus guttatus (Scrophulariaceae). Evolution 56: 22- 30.

Cochran WG. 1947. Some consequences when the assumptions for the analysis of variance are not satisfied. Biometrics 3: 22-38.

DudAREVA N AND QuAlley AV. 2008. Aromatic Volatiles and Their Involvement in Plant Defense. In: SCHALLER A (Ed), Induced plant resistance to Herbivory. Aromatic Volatiles and their Involvement in Plant Defense. Springer Netherlands, p. 409-432.

EIGENBRODE SD AND ESPELIE KE. 1995. Effects of plant epicuticular lipids on insect herbivores. Annu Rev Entomol 40: 171-194.

FANCELLI M, VENDRAMIM JD, LOURENÇÃO AL AND DIAS CTS. 2003. Atratividade e preferência para oviposição de Bemisia tabaci (Gennadius) (Hemiptera: Aleyrodidae) biótipo $\mathrm{B}$ em genótipos de tomateiro. Neotrop Entomol 32: 319-328.

Fernandes MES, Silva DJH, Fernandes FL, PiCANÇO MC, Gontijo PC and Galdino TVS. 2009. Novos acessos de tomateiro resistentes à mosca-branca biótipo B. Pesqu Agropecu Bras 44: 1545-1548.

GoffredA JC, StefFens JC AND Mutschler MA. 1990 Association of epicuticular sugars with aphid resistance in hybrids with wild tomato. J Amer Soc Hort Sci 115: $161-165$

Gonçalves LD, Maluf WR, Cardoso MG, Resende JTV, CASTRO EM, SANTOS NM, NASCIMENTO IR AND FARIA MV. 2006. Relação entre zingibereno, tricomas foliares e repelência de tomateiros a Tetranychus evansi. Pesqu Agropecu Bras 41: 267-273.

KENNEDY GG. 2002. Tomato, pests, parasitoids and predators: tritrophic interactions involving the genus Lycopersicum. Annu Rev Entomol 8: 51-72.

Marim BG, Silva DJH, CARneiro PCS, Miranda GV, MATTEDI AP AND CALIMAN FRB. 2009. Variabilidade genética e importância relativa de caracteres em acessos de germoplasma de tomateiro. Pesqu Agropecu Bras 44: $1283-1290$.

MAYHEW PJ. 1997. Adaptive patterns of host-plant selection by phytophagous insects. Oikos 79: 417-428. MAYHEW PJ. 2001. Herbivore host choice and optimal bad motherhood. Tree 16: 165-167. 
OliveIRA FA, SILVA DJH, LEITE GLD, JHAM GN AND PICANÇO MC. 2009. Resistance of 57 greenhouse-grow accessions of Lycopersicum esculentum and three cultivars to Tuta absoluta (Meyrick) (Lepidoptera: Gelechiidae). Sci Hortic 119: 182-187.

PAINTER RH. 1951. Insect Resistance in Crop Plants. New York: The MacMillan, $520 \mathrm{p}$.

PANDA N AND KRUSH GS. 1995. Host plant resistance to pest. Guildford: Biddles, $431 \mathrm{p}$.

PARrella MP. 1987. Biology of Liriomyza. Annu Rev Entomol 32: 201-224.

Parrella MP, Allen WW AND Morishita P. 1981. Leafminer species causes California mum growers new problems. Calif Agric 35: 28-30.

Peralta IE, Knapp S AND Spooner DM. 2005. New species of wild tomatoes (Solanum Section Lycopersicum: Solanaceae) from northern Peru. Syst Bot 30: 424-434.

SchoOnhoven LM, VAN LOON JJA AND Dicke M. 2005. Insect-Plant Biology. Oxford, University Press, Oxford, $440 \mathrm{p}$.

SCOTT AJ AND KnOTT MA. 1974. A cluster analyses method for grouping means in the analyses of variance. Biometrics 30: 507-512.

Silva DJH, ABreu FB, CALiman FRB AND ANTÔNio AC. 2008. Origin, cultivation techniques and germplasm resources. In: VICTOR RP AND WATSON RR (Eds), Tomatoes and Tomato products. Plymouth: Science Publishers, p. 03-25.
SouZA JC AND REIS PR. 1999. Pragas da batata em Minas Gerais. EPAMIG: Belo Horizonte, 62 p.

SPOONER DM, ANDERSON GJ AND JANSEN RK. 1993. Chloroplast DNA evidence for the interrelationships of tomatoes, potatoes, and pepinos (Solanaceae). Am J Bot 80: 676-688.

SuINAGa FA, CASAli VWD, SILVA DJH AND PICANÇO MC. 2003. Dissimilaridade genética de fontes de resistência de Lycopersicum spp. a Tuta absoluta (Meyrick, 1917) (Lepidoptera: Gelechiidae). Rev Bras Agrocienc 9: 371-376.

SuINAGA FA, PICANÇO MC, JHAM GN AND BROMMONSCHENKEL SH. 1999. Causas químicas de resistência de Lycopersicum peruvianum (L.) a Tuta absoluta (Meyrick) (Lepidoptera: Gelechiidae). An Soc Entomol Bras 28: 313-321.

THOMPSON JN. 1988. Evolutionary ecology of the relationship between oviposition preference and perfornance of offspring in phytophagous insects. Entomol Exp Appl 47: 3-14.

YANG G, Wisemam BR, IsEnhour DJ AND EsPILIE HE. 1993. Chemical and ultra strutural analysis of corn cuticular lipids and their effect on feeding by fall armyworm larvae. J Chem Ecol 9: 2055-2074. 